\title{
Uptake of cadmium and zinc by ryegrass at high solution culture levels
}

\author{
W. Dijkshoorn, J. E. M. Lampe and A. R. Kowsoleea
}

Institute for Biological and Chemical Research on Field Crops and Herbage (IBS), Wageningen, the Netherlands

Accepted: 5 March 1975

\section{Summary}

New top growth of ryegrass exposed to various solution culture levels of cadmium and zinc absorbed the elements without detectable interaction between the two. When after repeated clippings the contents had risen to $100 \mathrm{mg}$ cadmium $/ \mathrm{kg} \mathrm{DM}$ or 700-1000 $\mathrm{mg}$ zinc/ $\mathrm{kg} \mathrm{DM}$ the new growth was injured. Interaction of zinc in cadmium toleration was suggested by the response of growth but could not be established with certainty.

\section{Introduction}

In previous work ryegrass in $\mathrm{Cd}$-containing solution culture was clipped at 12 -day intervals. After each defoliation more $\mathrm{Cd}$ moved to the new top growth and its concentration increased in successive clippings eventually to $100 \mathrm{mg} \mathrm{Cd} / \mathrm{kg} \mathrm{DM}$ with consequent injury. At very high ambient levels the uptake rose quickly to still higher and lethal concentrations in the new growth with a sharp drop in yield of a few heavily injured clippings and subsequent death of the plants (Dijkshoorn et al., 1974).

The present work concerns $\mathrm{Cd}-\mathrm{Zn}$ combinations. The highest $\mathrm{Cd}$ dose was that intended to produce toxic contents in later clippings. The highest dose of $\mathrm{Zn}$ was equimolecular to that of $\mathrm{Cd}$.

In view of their chemical similarity some degree of interaction between $\mathrm{Cd}$ and $\mathrm{Zn}$ was expected, and the treatments were planned to test its occurrence.

\section{Material and methods}

The technique was that of the previous communication. Cd was applied at rates of nil, 20, 40, 60, 80, 100 and $120 \mu \mathrm{mol} \mathrm{Cd} /$ litre, further denoted as Treatments $\mathrm{a}-\mathrm{g}$. To all nutrient solutions $0.8 \mu \mathrm{mol} \mathrm{Zn} /$ litre was added along with the trace elements needed for growth. In the $\mathrm{Cd}$ Series only $\mathrm{Cd}$ was varied at this low constant supply of $\mathrm{Zn}$. In the Cd-for-Zn Series extra $120 \mu \mathrm{mol} \mathrm{Zn/litre} \mathrm{was} \mathrm{added}$ at nil $\mathrm{Cd}$ and, while $\mathrm{Cd}$ was raised, $\mathrm{Zn}$ was diminished by amounts equivalent to 
the added $\mathrm{Cd}$ with $\mathrm{Cd}+\mathrm{Zn}$ constant at $120 \mu \mathrm{mol} / \mathrm{litre}$. $\mathrm{Cd}$ and extra $\mathrm{Zn}$ were added as the sulphates in standard solutions containing $2 \mathrm{~mol} \mathrm{Na}_{2} \mathrm{H}_{2} \mathrm{EDTA} / \mathrm{mol}$ $\mathrm{Cd}$ or $\mathrm{Zn}$ and $3 \mathrm{~mol} \mathrm{KOH} / \mathrm{mol} \mathrm{Cd}$ or $\mathrm{Zn}$ for neutralization.

Freshly defoliated sets of plants, previously established in Hoagland nutrient solutions, were transferred to those containing $\mathrm{Cd}$ on 29 August. The grass was clipped five times at successive intervals of 12, 15, 17, 21 and 25 days. Growth durations were made longer to compensate for the decrease in input of light in the autumn greenhouse climate. This and extra artificial lightening could not prevent a drop in yield and after 5 clippings the experiment was suspended.

\section{Results and discussion}

Uptakes were calculated as $\mathrm{kg} \mathrm{DM}$ in the new top growth multiplied by the measured concentration in $\mathrm{mg} \mathrm{Cd}$ or $\mathrm{Zn} / \mathrm{kg} \mathrm{DM}$, and cumulative uptakes and yields by adding the uptakes and dry weights of previous clippings to those of the succeeding one. These total outputs are shown in Fig. 1 for the Cd-for- $\mathrm{Zn}$ series of treatments. To cover the wide range of metal outputs, equal logarithmic scales were used for $\mathrm{Cd}$ and $\mathrm{Zn}$ as ordinates and dry weights as abscissas. In this type of graph proportionality and consequent constancy of $\mathrm{mg} / \mathrm{kg} \mathrm{DM}$ are indicated by straight $45^{\circ}$ lines.

To obtain convenient plots with the units $\mathrm{mg} \mathrm{Cd}$ or $\mathrm{Zn}$ and $\mathrm{kg} \mathrm{DM}$ in whole numbers, all quantities per pot have been multiplied by 100 . From the intercept
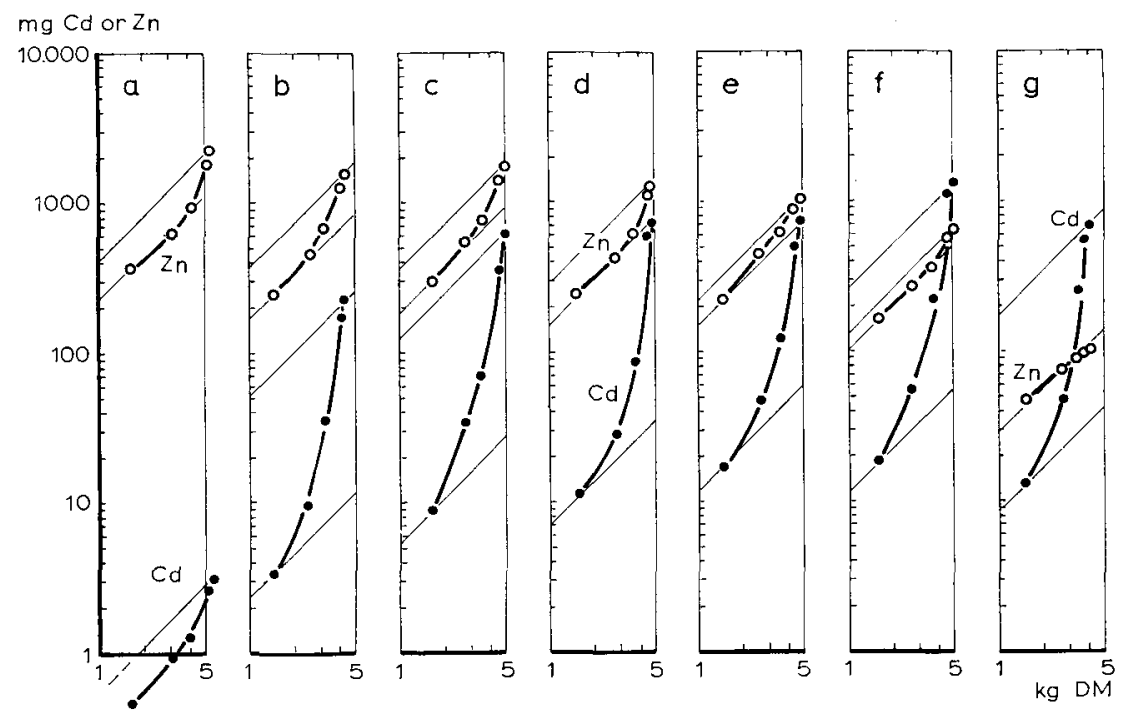

Fig. 1. Cumulative uptakes of $\mathrm{mg} \mathrm{Cd}$ (solid dots), and $\mathrm{mg} \mathrm{Zn}$ (open dots) per 100 pots, plotted against the cumulative yields of $\mathrm{DM}$ at the Treatments a $-\mathrm{g}$ with the various $\mathrm{Zn}-\mathrm{Cd}$ combinations. 
of a $45^{\circ}$ line through a point with the ordinate raised at $1 \mathrm{~kg} \mathrm{DM}$, the corresponding concentration in the conventional unit $\mathrm{mg} / \mathrm{kg}$ DM can be read off.

Height and width of the curves are a measure of the progressive relative increments from Cut 1 to the combined Cuts $1-5$. Repeated clippings raised the yield from 1.5 to $5 \mathrm{~kg} \mathrm{DM} / 100$ pots or 3.5 -fold in the 90 -day test period. The DM range was narrower than the 6-fold increase for the first five cuts of the previous experiment obtained within 60 days. But the 60 -fold range in Cd output was wider and the present experiment produced more upright curves with steeper slopes: $\mathrm{Cd}$ concentrated with the number of fall clippings of longer growth duration more steeply than occurred in the summer climate with rapid growth maintained in full light. Higher concentrations of plant constituents in autumn, when the growth rate falls, is a common observation.

The intercepts with the ordinate at $1 \mathrm{~kg} \mathrm{DM}$ of the $45^{\circ}$ lines bracketing the curves show that treatments $\mathrm{c}-\mathrm{f}$ produced first cuts containing $5-10 \mathrm{mg} \mathrm{Cd} / \mathrm{kg}$ $\mathrm{DM}$ and, throughout the test period, combined Cuts $1-5$ with $100-250 \mathrm{mg} \mathrm{Cd}$ / $\mathrm{kg} \mathrm{DM}$. The treatments a-f were equally productive and the new growth remained healthy in appearance. Only at the Highest Cd-Lowest $\mathrm{Zn}$ treatment $(\mathrm{g})$ the later new growth looked injured with a drop in total output from 1300 to $700 \mathrm{mg} \mathrm{Cd}$ and from 5 to $4 \mathrm{~kg} \mathrm{DM} / 100$ pots. The concentration of $\mathrm{Cd}$ in the combined five clippings dropped from 260 at treatment $\mathrm{f}$ to $175 \mathrm{mg} \mathrm{Cd} / \mathrm{kg} \mathrm{DM}$ at treatment $\mathrm{g}$. Change in leaf colour, smaller new growth, and less $\mathrm{mg} \mathrm{Cd} / \mathrm{kg} \mathrm{DM}$ were the effects of prolonged exposure to injurious amounts of $\mathrm{Cd}$ in the tissues already known from the previous experiment.

Uptake of $\mathrm{Zn}$ was highest at the Lowest Cd-Highest $\mathrm{Zn}$ treatment (a), and declined from treatment a to treatment $\mathrm{g}$ when more of the added $\mathrm{Zn}$ had been replaced by $\mathrm{Cd}$ in the medium. The upward-trending curves with slopes steeper than $45^{\circ}$ show that each succeeding cut contained more $\mathrm{Cd}$ and $\mathrm{Zn}$ relative to $\mathrm{DM}$ than the previous one: concentrations in the new growth increased with the number of previous clippings. Only at the Highest Cd-Lowest $\mathrm{Zn}$ treatment (g) the dots for $\mathrm{Zn}$ lie along a $45^{\circ}$ line as for proportionate increments at a nearly constant low level of $30 \mathrm{mg} \mathrm{Zn} / \mathrm{kg} \mathrm{DM}$.

In the $\mathrm{Cd}$ series with $\mathrm{Cd}$ as the only variable at low constant $\mathrm{Zn}$, injured and smaller new growth at higher $\mathrm{Cd}$ ranged from treatment $d$ to treatment $\mathrm{g}$, instead of being restricted to the heaviest $\mathrm{Cd}$ treatment $(\mathrm{g})$ as in the $\mathrm{Cd}$-for- $\mathrm{Zn}$ series. From this it seemed that extra $\mathrm{Zn}$ enabled the plants to withstand a higher level of $\mathrm{Cd}$ than they could ordinarily tolerate.

It may be well at this stage to continue with the original measurements of concentrations in the individual clippings. The frequently renewed media underwent only minor depletion of $\mathrm{Cd}$ and $\mathrm{Zn}$ which means that differences in yield cannot have led to differences in the degree of exhaustion as an extra source of differences in their concentrations in the grass.

To accentuate relative changes over the wide range of concentrations in the new growth of the individual Cuts $1-5$ these have been plotted as ordinates along a logarithmic scale in Fig. 2 and 3. The same scale was used to plot the yields in dekagrammes $\mathrm{DM} /$ pot. The abscissas denote the external concentrations of $\mathrm{Cd}$ 


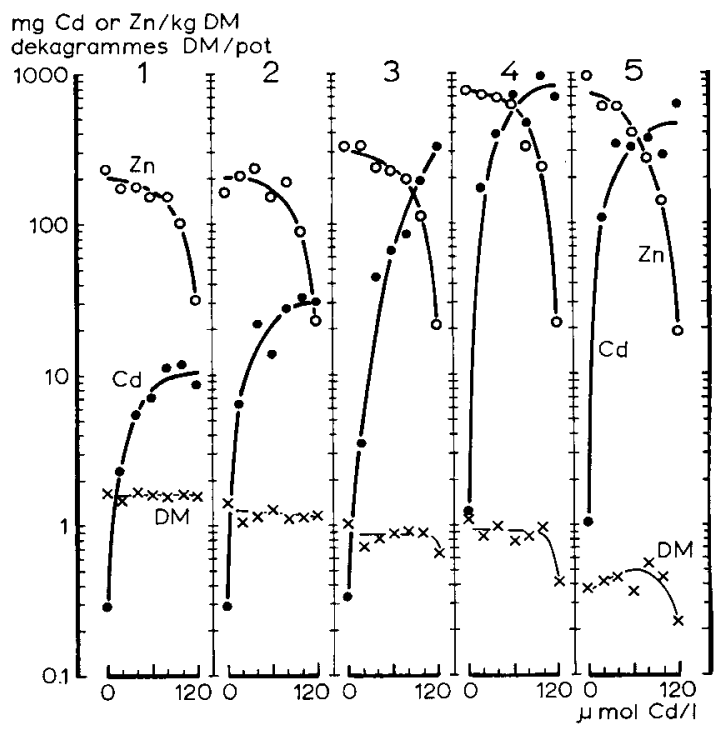

Fig. 2. Concentrations of $\mathrm{Cd}$ and $\mathrm{Zn}$ in $\mathrm{mg} / \mathrm{kg} \mathrm{DM}$ in the successive Cuts 1 - 5 produced by the Cd-for-Zn treatments. Abscissas: external concentrations of Cd. Yields (crosses) in dekagrammes $\mathrm{DM} /$ pot.

with or without partnered $\mathrm{Zn}$.

Fig. 2 concerns the $\mathrm{Cd}$-for- $\mathrm{Zn}$ series. After the decrease in $\mathrm{Zn}$ with the increase in supply of $\mathrm{Cd}$, the descending curves for $\mathrm{Zn}$ are mirrored by ascending curves for $\mathrm{Cd}$.

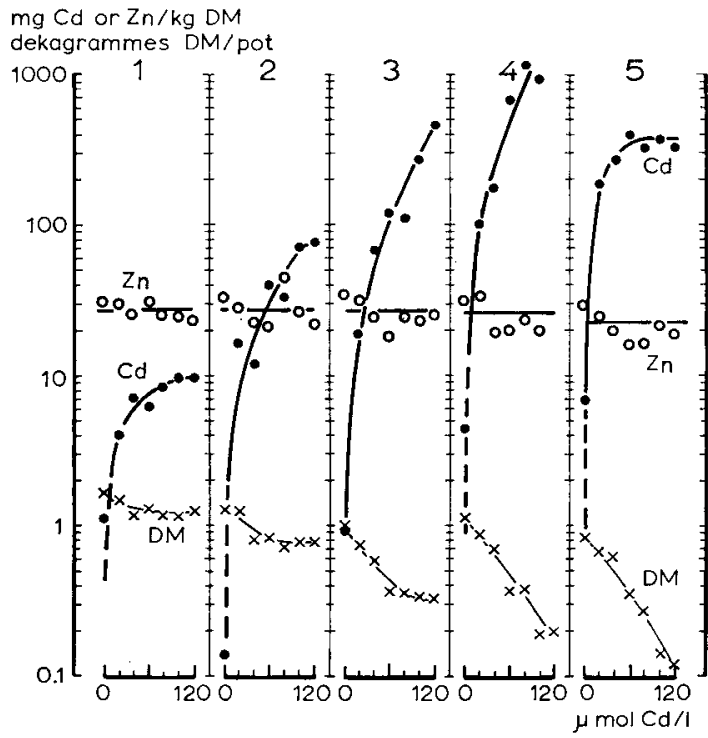

Fig. 3. Same as Fig. 2, but for the treatments with $\mathrm{Cd}$ as the only variable at low constant $\mathrm{Zn}$. 
Fig. 3 is for the $\mathrm{Cd}$ series with increasing $\mathrm{Cd}$ as the only variable, in which $\mathrm{Zn}$ in the new growth remained low and constant at about $20-30 \mathrm{mg} \mathrm{Zn} / \mathrm{kg} \mathrm{DM}$, and Cd increased as in Fig. 2.

$\mathrm{Cd}$ rose steeply in the tops with the first few additions of $\mathrm{Cd}$ and tended towards a plateau at high $\mathrm{Cd}$ which was least in Cut $1(10 \mathrm{mg} \mathrm{Cd} / \mathrm{kg} \mathrm{DM})$ and highest in Cut 4 (about $800 \mathrm{mg} \mathrm{Cd} / \mathrm{kg} \mathrm{DM}$ ). The maximum was not a constant character of the new growth but increased with the number of previous clippings, and presumably followed a progressive increase in the amount of $\mathrm{Cd}$ stored by the lower portions of the plant that remained after defoliation.

A true maximum was attained at Cut 4 at which injurious amounts of $\mathrm{Cd}$ were spread out over the whole plant with partial obstruction of the transfer system to yield lower maximum concentrations of $\mathrm{Cd}$ in the subsequent new top growth of Cut 5.

As Cd is not essential for growth, there will be no lowest possible limit in $\mathrm{mg}$ $\mathrm{Cd} / \mathrm{kg} \mathrm{DM}$. Zn, a nutrient essential for growth, has a minimum of the order of $10 \mathrm{mg} \mathrm{Zn} / \mathrm{kg} \mathrm{DM}$ which permits no further dilution by DM gain, and would stop the growth upon removal of $\mathrm{Zn}$ from the supply. Its upper limit is set by toxicity and must be of the order of 700-1000 mg Zn/ $\mathrm{kg} \mathrm{DM}$, because at this level of tissue $\mathrm{Zn}$ the new growth of Cut 5 at Nil Cd-Highest $\mathrm{Zn}$ (Fig. 2) was small and injured whereas at Nil Cd-Low Zn (Fig. 3) it was higher yielding and healthy. There would remain a 100 -fold range of possible $\mathrm{Zn}$ contents from the minimum metabolic demand up to toleration of excess.

Toxicity produced small injured growth of Cut 5 at all the $\mathrm{Cd}-\mathrm{Zn}$ combinations of Fig. 2 as at low $\mathrm{Zn}$, high $\mathrm{Cd}$ and at low $\mathrm{Cd}$, high $\mathrm{Zn}$ had become toxic for growth. In the $\mathrm{Cd}$ series with low $\mathrm{Zn}$, the plants were injured only by high $\mathrm{Cd}$ and the yield of Cut 5 dropped from an initially higher value more steeply with the increase in Cd in Fig. 3 than it did among the lower yielding Co-for-Zn treatments of Fig. 2 which merely changed from toxic $\mathrm{Zn}$ to toxic $\mathrm{Cd}$.

A survey of the graphs reveals that toxic levels exceeding $100 \mathrm{mg} \mathrm{Cd} / \mathrm{kg} \mathrm{DM}$ were attained from the third cutting date onwards. In Fig. 3 there remains no doubt that the yield of DM dropped under the influence of higher Cd: growth of Cuts 3, 4 and 5 was smaller and visibly injured in the range of the heavier treatments. But in Fig. 2 with the Cd-Zn combinations only the Highest Cd-Lowest Zn treatment was toxic. From the first substitution of one-sixth of the maximum $\mathrm{Cd}$ dose by $\mathrm{Zn}$ the $\mathrm{Zn}$ content increased from 20 to $100 \mathrm{mg} \mathrm{Zn} / \mathrm{kg} \mathrm{DM}$ and higher, and these plants with extra $\mathrm{Zn}$ remained healthy and grew well until high $\mathrm{Zn}$ became toxic in the later new growth of Cut 5 .

The identical Highest Cd treatments of Fig. 2 and 3 differed in yield of DM. A contributory source to this dispersion was an incidental decline of the original stand density among the sets of plants used in Fig. 3 as reflected by a $20 \%$ yield reduction at pre-treatment harvest and in Cut 1 with still non-toxic levels of Cd. But the effect of this planting error was small compared with that of treatment.

The more important source of dispersion was an unexplained quicker accumulation of $\mathrm{Cd}$ in Fig. 3 even at the identical Highest $\mathrm{Cd}$-Lowest $\mathrm{Zn}$ treatments of Fig. 2 and 3 as the evidence that it was independent of extra $\mathrm{Zn}$. At the midpoint 
treatment, with $60 \mu \mathrm{mol} \mathrm{Cd} /$ litre and with or without $60 \mu \mathrm{mol} \mathrm{Zn/litre,} \mathrm{Cuts} 1$, 2,3 and 4 contained $7,22,65$ and $500 \mathrm{mg} \mathrm{Cd} / \mathrm{kg}$ DM respectively, with high tissue $\mathrm{Zn}$ in Fig. 2 and 7, 30, 100 and $500 \mathrm{mg} \mathrm{Cd} / \mathrm{kg} \mathrm{DM}$, respectively, with low $\mathrm{Zn}$ in Fig. 3. At high $\mathrm{Zn}$ the repeated new growth remained healthy and productive, but at low $\mathrm{Zn}$ all the new growth containing $100 \mathrm{mg} \mathrm{Cd} / \mathrm{kg} \mathrm{DM}$ or more was hit by $\mathrm{Cd}$ toxicity with a $50 \%$ reduction in yield.

Cut 4 alone would suggest that the $500 \mathrm{mg} \mathrm{Cd} / \mathrm{kg}$ DM was toxic at low $\mathrm{Zn}$ in Fig. 3, but rendered non-toxic by the extra $600 \mathrm{mg} \mathrm{Zn/kg} \mathrm{DM} \mathrm{contained} \mathrm{by} \mathrm{the}$ new growth of Fig. 2. But, perhaps by chance, the previous new growth of Cut 3 contained $100 \mathrm{mg} \mathrm{Cd} / \mathrm{kg} \mathrm{DM}$ at low $\mathrm{Zn}$, but only $65 \mathrm{mg} \mathrm{Cd} / \mathrm{kg} \mathrm{DM}$ at high $\mathrm{Zn}$. As tolerance involves time of exposure, not high $\mathrm{Zn}$, but the lower $\mathrm{Cd}$ content of the preceeding Cut 3 may have contributed to the greater tolerance to $500 \mathrm{mg}$ $\mathrm{Cd} / \mathrm{kg} \mathrm{DM}$ measured at the fourth cutting date because it came from a lower, less toxic level during the first new growth of Cut 4 than was the case in the plants at low $\mathrm{Zn}$ and Cut 3 already at $100 \mathrm{mg} \mathrm{Cd} / \mathrm{kg} \mathrm{DM}$.

The data of Cut 5 are not forthcoming in the decision because at test conclusion the onset of $\mathrm{Zn}$ toxicity at Low Cd-High $\mathrm{Zn}$ (Fig. 2), and of obstruction in the uptake mechanism of $\mathrm{Cd}$ at High Cd-Low $\mathrm{Zn}$ (Fig. 2 and 3), created a new situation which was the result rather than a continuation of the previous trend.

Largely on account of this difference in rate of $\mathrm{Cd}$ accumulation between the high and low $\mathrm{Zn}$ groups we are unable to establish whether high $\mathrm{Zn}$ protected the plants against toxicity of $\mathrm{Cd}$, as was anticipated from the very conspicuous differences in response to high Cd levels between the plants high and low in tissue $\mathrm{Zn}$.

In Fig. 2 the curves for $\mathrm{Cd}$ and $\mathrm{Zn}$ are both concave with respect to the horizontal axis of external concentrations which indicates that uptake and transport of $\mathrm{Cd}$ and $\mathrm{Zn}$ to the tops were of a non-competitive nature. The form of the Cd curves of Fig. 2 and 3 are similar. The combined evidence shows that $\mathrm{Cd}$ and $\mathrm{Zn}$ were delivered to the new top growth in a way completely independent of one another.

\section{Reference}

Dijkshoorn, W., J. E. M. Lampe \& A. R. Kowsoleea, 1974. Tolerance of ryegrass to cadmium accumulation. Neth. J. agric. Sci. 22: 66-71. 